\title{
Characterization of a novel marine microbial esterase and its use to make D-methyl lactate
}

\author{
Yilong Wang a,b, Yun Zhang a,c, Aijun Sun a,c, Yunfeng Hu a,c,d,* \\ a Key Laboratory of Tropical Marine Bio-resources and Ecology, South China Sea Institute of Oceanology, Chinese Academy of Sciences, Guangzhou \\ 510301, Guangdong, China \\ b University of Chinese Academy of Sciences, Beijing 100049, China \\ c Guangdong Key Laboratory of Marine Materia Medica, South China Sea Institute of Oceanology, Chinese Academy of Sciences, Guangzhou 510301, \\ Guangdong, China \\ d South China Sea Bio-Resource Exploitation and Utilization Collaborative Innovation Center, Guangzhou 510275, Guangdong, China
}

\section{A R T I C L E I N F O}

\section{Article history:}

Received 25 May 2016

Accepted 22 June 2016

Published 5 August 2016

\section{Keywords:}

Esterase

Marine microorganism

Biocatalysis

Kinetic resolution

D-methyl lactate

Hydrolysis

\begin{abstract}
A B S T R A C T
A novel marine microbial esterase PHE14 was cloned from the genome of Pseudomonas oryzihabitans HUP022 isolated from the deep sea of the western Pacific Ocean. Esterase PHE14 exhibited very good tolerance to most organic solvents, surfactants and metal ions tested, thus making it a good esterase candidate for organic synthesis that requires an organic solvent, surfactants or metal ions. Esterase PHE14 was utilized as a biocatalyst in the asymmetric synthesis of D-methyl lactate by enzymatic kinetic resolution. D-methyl lactate is a key chiral chemical. Contrary to some previous reports, the addition of an organic solvent and surfactants in the enzymatic reaction did not have a beneficial effect on the kinetic resolution catalyzed by esterase PHE14. Our study is the first report on the preparation of the enantiomerically enriched product D-methyl lactate by enzymatic kinetic resolution. The desired enantiomerically enriched product D-methyl lactate was obtained with a high enantiomeric excess of $99 \%$ and yield of $88.7 \%$ after process optimization. The deep sea microbial esterase PHE14 is a green biocatalyst with very good potential in asymmetric synthesis in industry and can replace the traditional organic synthesis that causes pollution to the environment.
\end{abstract}

(C) 2016, Dalian Institute of Chemical Physics, Chinese Academy of Sciences.

Published by Elsevier B.V. All rights reserved.

\section{Introduction}

The enantiomers of drugs have dramatically different biological activities and toxicities. Chiral drugs are more clinically acceptable as they reduce the potential toxicity of racemic drugs. Chiral intermediates are crucial building blocks for the synthesis of valuable chiral drugs and the synthesis of the chiral intermediates of drugs is important in the pharmaceutical industry [1-3].
Chiral $\alpha$-hydroxy acids, e.g. chiral lactic acid, are important building blocks in the synthesis of many drugs, pesticides and polymers $[4,5]$. The preparation of chiral lactic acid is of great importance in both the pharmaceutical and material industries. The synthesis of chiral chemicals like chiral lactic acid is not easily achieved by traditional organic synthesis due to the low enantio-selectivity of traditional metallic organic synthesis [5].

The synthesis of enantiomerically enriched chemicals can also be achieved by biocatalytic methods using enzymes, which

\footnotetext{
* Corresponding author. Tel: +86-20-89024092; Fax: +86-20-84451672; E-mail: yunfeng.hu@scsio.ac.cn This work was supported by the Strategic Priority Research Program of the Chinese Academy of Sciences (XDA11030404), the National Natural Science Foundation of China (21302199), Guangzhou Science and Technology Plan Projects (201510010012) and Key Project from the Chinese Academy of Sciences (KGZD-EW-606).
}

DOI: 10.1016/S1872-2067(16)62495-6 | http://www.sciencedirect.com/science/journal/18722067 | Chin. J. Catal., Vol. 37, No. 8, August 2016 
avoid the harsh working conditions and pollution by metallic organic synthesis [6,7]. Due to the existence of one hydroxy group and one acid group in lactic acid, the synthesis of enantiomerically enriched lactic acid can be accomplished by the asymmetric reduction of ketone precursors using dehydrogenases. However, the biocatalytic method using dehydrogenases require expensive co-factors such as NADH and NADPH [8]. Another biocatalytic method is by asymmetric hydrolysis of racemic esters using esterases or lipases. L-lactic acid is not expensive because currently L-lactic acid can be directly obtained using large scale fermentation instead of an organic or enzymatic method $[9,10]$. D-lactic acid, which is a chiral chemical of great demand in industry, cannot be directly obtained using the inexpensive fermentation method and is thus more expensive [4]. Biocatalytic methods are the major methods for the preparation of D-lactic acid and its ester derivatives with high enantiomeric excess.

Here, we identified a novel marine microbial esterase, PHE14, from the deep seas of the western Pacific Ocean and characterized its functionalities. We also utilized esterase PHE14 as a biocatalyst for the enzymatic synthesis of D-methyl lactate. The desired chiral product D-methyl lactate was obtained with high enantiomeric excess and yield after process optimization.

\section{Experimental}

\subsection{Microorganisms and reagents}

E.coli DH5 $\alpha$ and E.coli BL21 (DE3) were used as the host strains for gene cloning and protein expression, respectively. Plasmid pET-28a (+) (Novagen, USA) was used as the expression vector of the enzymes. TransStart $\AA$ FastPfu DNA PolyMerase, ligases and restriction enzymes were all purchased from TransGen Biotech (Beijing, China). $p$-nitrophenyl ( $p$-NP) esters were obtained from Sigma (St. Louis, MO, USA). Racemic methyl lactate and the corresponding chiral enantiomers were all purchased from Aladdin Industrial Corporation (Shanghai, China). Other chemicals were analytical grade.

\subsection{Gene cloning and expression vector construction}

The strain Pseudomonas oryzihabitans HUP022 was isolated from the sediments obtained from the deep sea of the western Pacific Ocean. The sequencing of the whole genome of Pseudomonas oryzihabitans HUP022 was completed by Genewiz Inc. The coding DNA sequence of an esterase (named PHE14) was amplified from the genomic DNA of Pseudomonas oryzihabitans HUP022 with a pair of primers (forward: 5' CACGAATTCGTGCTGGAATCGCCTAGC-3', reverse: ${ }^{\prime}$ CCGCTCGAGTTATTTTTTGCCGAGACGTGCC-3'). The primer sequences contained the EcoR I and Xho I (underlined) restriction sites. The PCR products were cloned into the EcoR I and Xho I sites of the expression vector pET-28a (+). Recombinant plasmids were confirmed by sequencing from Majorbio Ltd. (Shanghai, China) and then transformed into E. coli BL21 (DE3) according to standard protocols.

\subsection{Expression and purification of PHE14}

The $E$. coli and recombinant $E$. coli strains were incubated at $37{ }^{\circ} \mathrm{C}$ and $200 \mathrm{r} / \mathrm{min}$ in Luria-Bertani medium (recombinant strains with $50 \mu \mathrm{g} / \mathrm{mL}$ kanamycin). As the cell density reached a turbidity of 0.6 at $600 \mathrm{~nm}, 0.3 \mathrm{mmol} / \mathrm{L}$ isopropyl-beta-D-thiogalactopyranoside (IPTG) was added to the culture for protein induction. After $18 \mathrm{~h}$ induction at $20^{\circ} \mathrm{C}$, the cells were harvested by centrifugation at $7500 \mathrm{r} / \mathrm{min}$ for 10 min, washed with phosphate buffer ( $50 \mathrm{mmol} / \mathrm{L}, \mathrm{pH} 7.5)$ two times and then re-suspended in the same buffer. The cells were disrupted by sonication on ice for $10 \mathrm{~min}$ and centrifuged (11500 r/min, $20 \mathrm{~min}, 4^{\circ} \mathrm{C}$ ). The recombinant protein PHE14 was purified and desalted using nickel-nitrilotriacetic acid agarose resin (GE Healthcare Life Science, China) and PD-10 desalting columns (GE Healthcare Life Sciences, China) according to the manufacturer's instructions. The protein concentration was measured by the method of Bradford, with bovine serum albumin as the standard. Purified PHE14 was examined by sodium dodecyl sulfate-polyacrylamide gel electrophoresis (SDS-PAGE) under denaturing conditions.

\subsection{Enzyme assay}

The hydrolytic activity of PHE14 was measured at $405 \mathrm{~nm}$ using the assay procedure described by Deng et al [11]. A standard reaction system containing $10-\mu \mathrm{L}$ substrate $(10$ mmol/L, dissolved in acetonitrile), $10-\mu \mathrm{L}(0.8 \mu \mathrm{g} / \mu \mathrm{L})$ enzyme, $940-\mu \mathrm{L}$ phosphate buffer (50 mmol/L, pH 7.5), and 40- $\mu \mathrm{L}$ ethanol was incubated at $35{ }^{\circ} \mathrm{C}$ for $5 \mathrm{~min}$. The esterase activity was analyzed by detecting the absorbance of $p$-NP at $405 \mathrm{~nm}$. One unit of enzyme activity was defined as the amount of esterase that liberated $1 \mu \mathrm{mol}$ of $p$-NP per minute.

\subsection{Biochemical characterization of purified PHE14}

The substrate specificity was determined using different substrates ( $p$-NP C2-C10) under standard reaction conditions. The optimum $\mathrm{pH}$ for PHE14 was determined using $p$-PN acetate (C2) as the substrate in different $\mathrm{pH}$ ranges: $50 \mathrm{mmol} / \mathrm{L}$ $\mathrm{NaAc} / \mathrm{HAc}$ (pH 5.0-6.0), $50 \mathrm{mmol} / \mathrm{L} \mathrm{Na}_{2} \mathrm{HPO}_{4} / \mathrm{NaH}_{2} \mathrm{PO}_{4}(\mathrm{pH}$ 6.5-8.0), $50 \mathrm{mmol} / \mathrm{L}$ Tris/HCl (pH 8.5-9.0) and $50 \mathrm{mmol} / \mathrm{L}$ Glycine/NaOH (pH 9.5-10.0). The pH stability was characterized by incubating purified PHE14 at $4{ }^{\circ} \mathrm{C}$ for $12 \mathrm{~h}$ in the buffer with different $\mathrm{pH}$ values. The optimum temperature was measured for the temperature range of 20 to $70{ }^{\circ} \mathrm{C}$ under the optimal $\mathrm{pH}$ value. The thermo-stability was measured by incubating PHE14 at different temperatures (from 20 to $60{ }^{\circ} \mathrm{C}$ ) for different times (0-60 min) using $p$-PN acetate (C2) as the substrate under optimal $\mathrm{pH}$ value. The effect of metal ions $\left(\mathrm{Li}^{+}, \mathrm{Na}^{+}\right.$, $\mathrm{K}^{+}, \mathrm{Mg}^{2+}, \mathrm{Ca}^{2+}, \mathrm{Fe}^{2+}, \mathrm{Ni}^{2+}, \mathrm{Mn}^{2+}$ ) on the activity of PHE14 was determined by incubating PHE14 in the presence of the metal ions ( $1 \mathrm{mmol} / \mathrm{L})$ for $12 \mathrm{~h}$ at $4{ }^{\circ} \mathrm{C}$. The effects of different organic solvents and surfactants were investigated in the presence of thirteen different organic solvents $(10 \%, v / v)$ and four different surfactants $(1 \%)$ by incubating PHE14 for $12 \mathrm{~h}$ at $4{ }^{\circ} \mathrm{C}$. The effect of salt concentration on PHE14 activity was studied by 
adding $\mathrm{NaCl}(0.2$ to $4 \mathrm{~mol} / \mathrm{L})$ into the incubation mixture and measuring the enzymatic activity after pre-incubation at $4{ }^{\circ} \mathrm{C}$ for $12 \mathrm{~h}$. Kinetic parameters were determined from a Lineweaver-Burk plot under the optimal reaction conditions.

\subsection{Optical resolution of racemic methyl lactate by PHE14}

A standard $500-\mu \mathrm{L}$ hydrolytic reaction system containing $140 \mu \mathrm{g}$ purified esterase PHE14, $50 \mathrm{mmol} / \mathrm{L}$ substrate (racemic methyl lactate) and $50 \mathrm{mmol} / \mathrm{L}$ phosphate buffer ( $\mathrm{pH} 7.5)$ was incubated at $37^{\circ} \mathrm{C}$ for $1 \mathrm{~h}$. After the completion of the enzymatic reaction, reaction samples were extracted with an equal volume of ethyl acetate and the organic phase was further analyzed to evaluate the enzymatic resolution of ( \pm )-methyl lactate.

\subsubsection{Gas chromatography analysis}

The enantiomeric excess of the reaction product was analyzed by GC (FULI GC-9700II) equipped with a $\mathrm{H}_{2}$ flame ionization detector and a 112-6632 CYCLOSIL-B chiral capillary column (30 $\mathrm{m} \times 0.25 \mathrm{~mm}$ ID, $0.25 \mu \mathrm{m} \mathrm{df})$.

\subsubsection{Optimization of the kinetic resolution of ( \pm )-methyl lactate by esterase PHE14}

A series of enzymatic reactions were carried out at different $\mathrm{pH}$ ranging from 6 to 11 for $1 \mathrm{~h}$ to determine the optimal $\mathrm{pH}$ for the resolution of $( \pm)$-methyl lactate. The effect of temperature on the resolution of $( \pm)$-methyl lactate was carried out at different temperatures ranging from 25 to $45^{\circ} \mathrm{C}$ for $1 \mathrm{~h}$. Under the optimum $\mathrm{pH}$ value and temperature, eleven different organic solvents $(10 \%, v / v)$ and four surfactants $(0.01 \%)$ were used as the reaction solvent to investigate the effect of the organic solvent and surfactant on the enzymatic reaction. Reactions without adding an organic solvent and surfactant were carried out as a control. ( \pm )-Methyl lactate of different concentrations (from 0.09 to $0.15 \mathrm{~mol} / \mathrm{L}$ ) was employed to determine the effect of the substrate concentration on the kinetic resolution of $( \pm)$-methyl lactate. Purified PHE14 was added to the reaction at final concentrations ranging from $1.31 \times 10^{4}$ to $6.55 \times 10^{4} \mathrm{U} / \mathrm{L}$ to study the effect of enzyme concentration on the kinetic resolution of $( \pm)$-methyl lactate. Under the optimum reaction conditions, with $0.14 \mathrm{mg}$ purified enzyme and $60 \mathrm{mmol} / \mathrm{L}$ substrate $( \pm)$-methyl lactate in the reaction, the product of the enzymatic reaction was regularly monitored at different times to study the effect of reaction time on the enantiomeric excess of the residual methyl lactate. All the products were analyzed by chiral GC to determine the conversion of ( \pm )-methyl lactate.

\section{Results and discussion}

\subsection{Sequence analysis of PHE14}

The sequence analysis showed that the gene PHE14 encoded a protein composed of 214 amino acids without a signal peptide. Secretion signal was predicted by the SignalP 4.0 prediction tool from http://www.cbs.dtu.dk/services/SignalP/. The gene PHE14 was cloned from the genome of P. oryzihabit- ans HUP022, a marine microorganism identified from the deep sea of the western Pacific Ocean (the sequence of gene PHE14 has been deposited in GenBank with the accession no. KX397626). The protein sequence alignment with microbial esterases revealed that enzyme PHE14 exhibited its maximum identity with a putative esterase (WP_017639130.1) from Pseudomonas sp. 313 (96\%) and with a putative esterase (WP_007161882.1) from Pseudomonas psychrotolerans (96\%). The functions of these putative esterases have not been characterized before. In addition, the protein sequence analysis showed that PHE14 belonged to the $\alpha / \beta$ hydrolase family with the conserved signature (Gly-X-Ser-X-Gly) in the ORF. The three dimensional structure of PHE14 consists of five $\beta$ strands and five $\alpha$ helices, and revealed that its catalytic triad is formed by the three residues (Ser ${ }^{110}$, Asp $^{162}$, and His ${ }^{193}$ ) located at the $C$ terminal of the main parallel $\beta$ sheet. This was consistent with previous esterase sequence information with Ser ${ }^{110}$ being part of the characteristic Gly-X-Ser-X-Gly sequence [12,13]. Thus, Ser ${ }^{110}$, Asp ${ }^{162}$, and His ${ }^{193}$ are indispensable amino acid residues in the biochemical characterization of PHE14.

\subsection{Expression and purification of PHE14}

PHE14 was purified by Ni-NTA affinity chromatography. The nominal molecular weight and $\mathrm{pI}$ of PHE14 were calculated to be $28 \mathrm{kDa}$ and 4.94 by http://web.expasy.org/compute_pi/.

\subsection{Biochemical characterization of PHE14}

\subsubsection{Substrate specificity of PHE14}

$p$-PN acetate (C2) was the preferred substrate for hydrolysis and referenced as $100 \%$ relative activity. However, PHE14 displayed low activity for C8 and C10 substrates.

\subsubsection{Effect of $p H$ on the activity of PHE14}

The effect of $\mathrm{pH}$ on the PHE14 activity was measured over a pH range of 6.0-10.0 with $p$-PN acetate (C2) as the substrate. The optimal $\mathrm{pH}$ for the hydrolytic activity of esterase PHE14 was 9.0. The stability of PHE14 versus $\mathrm{pH}$ was studied after incubating PHE14 with different $\mathrm{pH}$ values ( $\mathrm{pH}$ 6.0-10.0) for $12 \mathrm{~h}$. Its activity was almost unchanged. The results showed PHE14 exhibited high activity and stability in a buffer of various $\mathrm{pH}$ values.

\subsubsection{Effect of temperature on the activity of PHE14}

PHE14 exhibited its highest hydrolytic activity at $60^{\circ} \mathrm{C}$. The thermal stability of PHE14 versus temperature was studied after incubating PHE14 at different temperatures $\left(20-60{ }^{\circ} \mathrm{C}\right)$ for different times (0-60 min). PHE14 exhibited its highest activity and stability at $35{ }^{\circ} \mathrm{C}$. It could retain $(85.6 \pm 0.7) \%$ of its maximum activities after incubation at $35^{\circ} \mathrm{C}$ for $1 \mathrm{~h}$. The stability of PHE14 decreased rapidly when the temperature was over $40{ }^{\circ} \mathrm{C}$.

\subsubsection{Effect of organic solvent and surfactant on the activity of PHE14}

The esterase PHE14 was studied by incubating PHE21 in the 
presence of different organic solvents(10\%, $v / v)$ and different surfactants $(1 \%)$ for $12 \mathrm{~h}$ at $4{ }^{\circ} \mathrm{C}$. The results showed that almost all the tested organic solvents and surfactants exhibited a positive effect on the hydrolysis activity of PHE14. Notably, the presence of dichlormethane and n-heptane $(10 \%, v / v)$ greatly promoted the hydrolysis activity of PHE14 with residual activities being $(136.2 \pm 4.5) \%$ and $(137.8 \pm 5.8) \%$, respectively.

\subsubsection{Effect of metal ions on the activity of PHE14}

The effect of various metal ions on the activity of esterase PHE14 was determined by incubating PHE14 in the presence of different metal ions $(1 \mathrm{mmol} / \mathrm{L})$ for $12 \mathrm{~h}$ at $4{ }^{\circ} \mathrm{C}$. The results indicated that most tested metal ions had no obvious effect on PHE14 except for $\mathrm{Co}^{2+}((50.9 \pm 1.0) \%)$ and $\mathrm{Zn}^{2+}((45.7 \pm 2.3) \%)$. The results indicated that PHE14 was a robust esterase with strong resistance to metal ions.

\subsubsection{Effect of $\mathrm{NaCl}$ concentration on the activity of PHE14}

Since the host of PHE14 was isolated from a marine environment, the tolerance of PHE14 to salt was tested by measuring the residual activity after incubation in solution containing 0.2 to $5 \mathrm{~mol} / \mathrm{L} \mathrm{NaCl}$ for $12 \mathrm{~h}$. The results showed that the addition of 0.2 to $1 \mathrm{~mol} / \mathrm{L} \mathrm{NaCl}$ increased the hydrolysis activity of PHE14. Furthermore, the hydrolysis activity of PHE14 retained more than $70 \%$ of its initial activity in the presence of $4 \mathrm{~mol} / \mathrm{L}$ $\mathrm{NaCl}$. The results indicated that PHE14 was a salt-tolerant esterase.

\subsubsection{Kinetic analysis of PHE14}

The kinetic analysis of PHE14 was performed using $p$-NP esters (C2-C8) as the substrates. The Km value for $p$-NP C2 was the highest and the $K \mathrm{~m}$ values for short chain $p$-PN esters (C2-C4) were higher than those of long chain $p$-PN esters (C6-C8). So PHE14 was further confirmed to be an esterase and not a lipase.

\subsection{Kinetic resolution of racemic methyl lactate by esterase PHE14}

3.4.1. Effect of $p H$ and temperature on the kinetic resolution of ( \pm )-methyl lactate

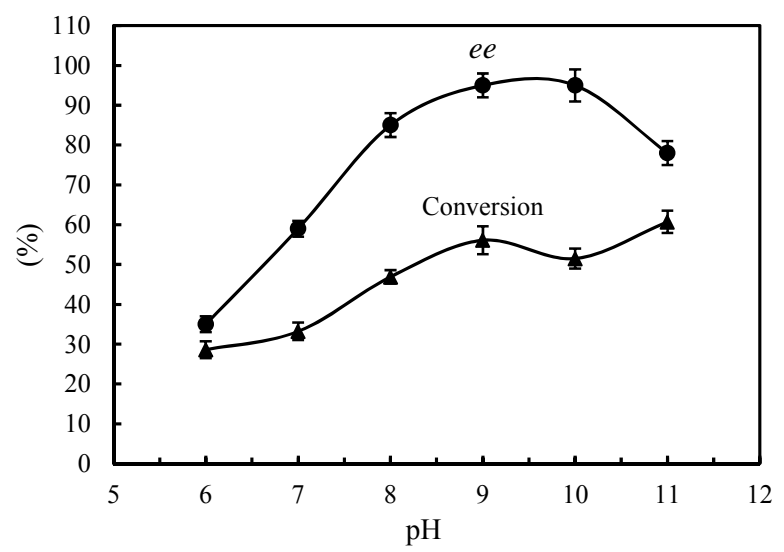

Fig. 1. Effect of $\mathrm{pH}$ on the kinetic resolution of ( \pm )-methyl lactate.

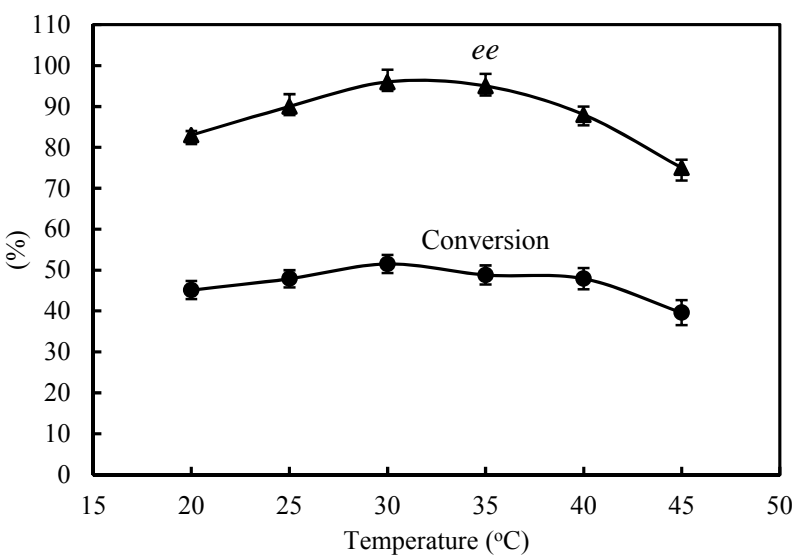

Fig. 2. Effect of temperature on the kinetic resolution of ( \pm )-methyl lactate.

The effect of $\mathrm{pH}$ and temperature on the kinetic resolution of $( \pm)$-methyl lactate by esterase PHE14 is shown in Fig. 1 and Fig. 2. The optimum reaction $\mathrm{pH}$ for the highest $e e_{\mathrm{s}}$ was $\mathrm{pH} 9.0$, with the $e e_{\mathrm{s}}$ being $95 \%$. However, the $e e_{\mathrm{s}}$ and conversion decreased dramatically when the $\mathrm{pH}$ values were below or over 9.0. The optimum reaction temperature for the highest $e e_{\mathrm{s}}$ was $30{ }^{\circ} \mathrm{C}$, with $e e_{\mathrm{s}}$ and yield being over $96 \%$ and $85.2 \%$, respectively. These results indicated that both the stereo-selectivity and catalytic activity were affected by the $\mathrm{pH}$ and temperature. In particular, the state of the active center of the enzyme, state of the substrate, and stability of the enzymes were all affected by $\mathrm{pH}$ and temperature.

\subsubsection{Effect of organic solvent and surfactant on the kinetic resolution of ( \pm )-methyl lactate}

Almost all the tested organic solvents and surfactants decreased both the $e e_{\text {s }}$ and conversion, thus inhibiting the kinetic resolution of $( \pm)$-methyl lactate by esterase PHE14 (Table 1 ). Thus, no organic solvent or surfactant was added to the enzymatic reactions for the further optimization of the kinetic resolution of $( \pm)$-methyl lactate by esterase PHE14.

Table 1

Effect of organic solvent and surfactant on the kinetic resolution of ( \pm )-methyl lactate.

\begin{tabular}{lcc}
\hline Organic solvents & $e e(\%)$ & Conversion (\%) \\
\hline Control & $96 \pm 1.2$ & $51.1 \pm 1.2$ \\
$n$-Hexane & $52 \pm 1.6$ & $29.1 \pm 0.7$ \\
Cyclohexane & $90 \pm 0.9$ & $47.4 \pm 0.6$ \\
$n$-Heptane & $93 \pm 1.7$ & $44.2 \pm 0.6$ \\
$n$-Decane & $90 \pm 0.8$ & $56.1 \pm 1.2$ \\
DMF & $56 \pm 0.5$ & $28.6 \pm 0.3$ \\
Acetonitrile & $45 \pm 1.2$ & $29.5 \pm 0.3$ \\
Isooctane & $90 \pm 0.5$ & $41.9 \pm 0.7$ \\
Methylbenzene & $66 \pm 0.8$ & $45.1 \pm 0.8$ \\
DMSO & $90 \pm 1.7$ & $46.0 \pm 0.7$ \\
Methanol & $82 \pm 0.8$ & $39.2 \pm 0.6$ \\
Ethanol & $64 \pm 1.2$ & $37.8 \pm 0.9$ \\
Triton X-100 & $84 \pm 1.2$ & $41.4 \pm 1.2$ \\
Tween-20 & $95 \pm 0.4$ & $54.7 \pm 1.5$ \\
Tween-80 & $94 \pm 0.8$ & $58.9 \pm 1.2$ \\
Sodium Tripolyphosphate & $95 \pm 1.2$ & $54.7 \pm 1.4$ \\
\hline
\end{tabular}




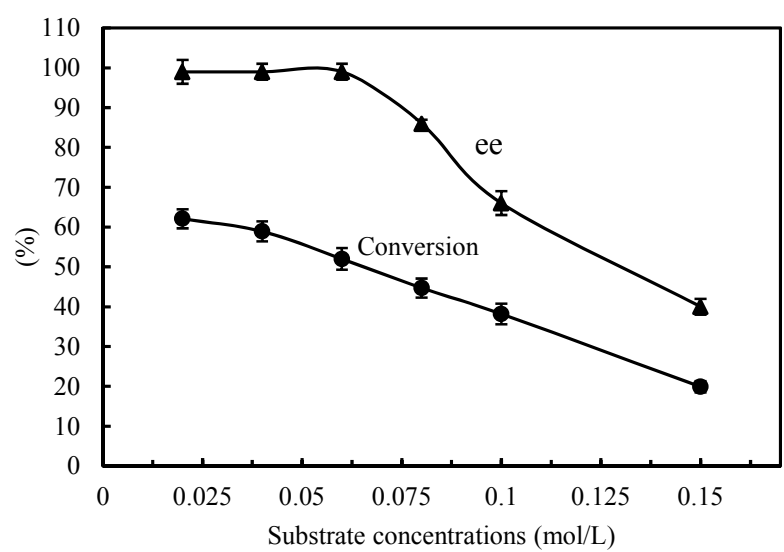

Fig. 3. Effect of substrate concentration on the kinetic resolution of ( \pm )-methyl lactate.

\subsubsection{Effect of substrate concentration and enzyme} concentration on the kinetic resolution of ( \pm )-methyl lactate

The amounts of substrate and enzyme used for the kinetic resolution of ( \pm )-methyl lactate were another two important factors that affect the conversion and enantio-selectivity. Fig. 3 and Fig. 4 show that $0.06 \mathrm{~mol} / \mathrm{L}$ substrate and $0.14 \mathrm{mg}$ enzyme were the optimum substrate concentration and enzyme concentration for the kinetic resolution of ( \pm )-methyl lactate by esterase PHE14, with an $e e_{\mathrm{s}}$ over 99\% and a yield of $86.1 \%$.

\subsubsection{Effect of reaction time on the kinetic resolution of ( \pm )-methyl lactate}

Under the optimum reaction conditions, different reaction times (from 20 to $120 \mathrm{~min}$ ) were used to investigate the optimal reaction time for the kinetic resolution of $( \pm)$-methyl lactate by PHE14. The results showed that the $e e_{\mathrm{s}}$ and the yield reach over $99 \%$ and $88.7 \%$, respectively, when the reaction time was $60 \mathrm{~min}$. The yield of D-methyl lactate in the reaction without added PHE14 was set as $100 \%$. However, when the reaction time was over $60 \mathrm{~min}$, the conversion was higher than $50 \%$ (Fig. 5). So, the optimal reaction time for the kinetic of $( \pm)$-methyl lactate was $60 \mathrm{~min}$.

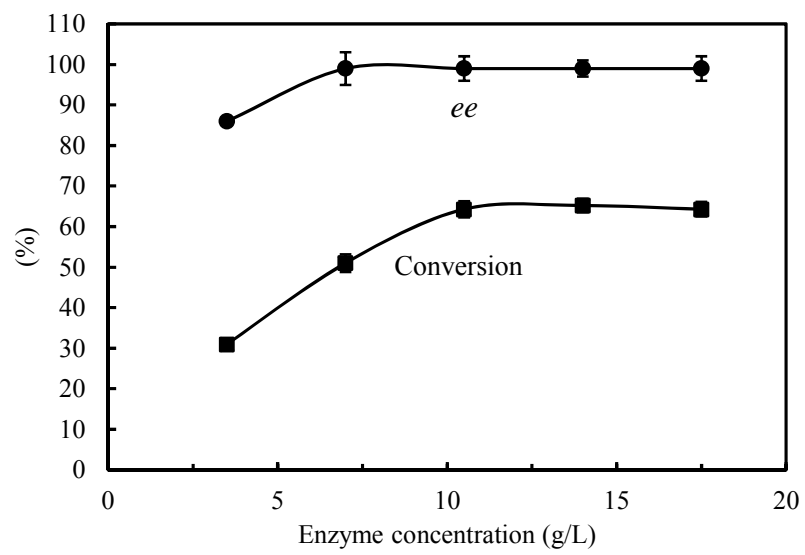

Fig. 4. Effect of enzyme concentration on the kinetic resolution of $( \pm)$-methyl lactate.

\subsection{Discussion}

We identified and functionally characterized a novel esterase, PHE14, from the genome of Pseudomonas oryzihabitans HUP022 isolated from the deep sea of the western Pacific Ocean. Under standard assay conditions, PHE14 preferred short chain $p$-NP ester substrates, and gave a $K_{\mathrm{m}}$ of $0.24 \pm 0.06$ $\mathrm{mmol} / \mathrm{L}$ and a specific activity of $293.07 \pm 3.24 \mathrm{U} / \mathrm{mg}$ for $p$-NP C2. However, PHE14 displayed low activity for C6 and C8 substrates. The hydrolytic activity of esterase PHE14 was higher than some other esterases, such as Ls-LeuDH (183 U/mg) [14], EM2L8 (156 U/mg) [15] and Est6 (104.41 U/mg ) [16], but lower than another esterase DAEEst6 (317 U/mg) [11]. The optimal $\mathrm{pH}$ and temperature for the hydrolysis activity of esterase PHE14 were 9.0 and $60{ }^{\circ} \mathrm{C}$, respectively. PHE14 exhibited its highest activity and stability at $35{ }^{\circ} \mathrm{C}$, and retained 85.59 $\pm 0.67 \%$ of its maximum activity after incubation at $35^{\circ} \mathrm{C}$ for 1 h. Similar results were also observed from an esterase EstIM1 from a metagenomic library of mountain soil with $80 \%$ residual activity after heating at $30{ }^{\circ} \mathrm{C}$ for $1 \mathrm{~h}$, but it was inactivated when heated at $40{ }^{\circ} \mathrm{C}$ for $40 \mathrm{~min}$ [17]. PHE14 was also quite stable in the presence of multiple organic solvents, surfactants and metal ions, thus making it a very good esterase candidate for organic synthesis that requires an organic solvent, surfactant or metal ion. Similar behavior was observed with other microbial esterases [18-21]. PHE14 was also characterized to be a salt-tolerant microbial esterase. Some other esterases such as EstKT4, EstKT7, and EstKT9 from the tidal flat sediments of Ganghwa Island in South Korea kept $40 \%, 10 \%$ and $40 \%$ of their initial activity in the presence of $4 \mathrm{~mol} / \mathrm{L} \mathrm{NaCl}$ [22-24].

Chiral $\alpha$-hydroxyl acids are an important class of chiral drug in the synthesis of a great variety of drugs, pesticides and polymers $[4,5,9]$. Due to the existence of one hydroxyl group and one acid group in lactic acid, the synthesis of chiral lactic acid can be achieved by enzymatic kinetic resolution catalyzed by a biocatalytic method instead of metallic organic synthesis $[7,25,26]$. Before our study, the preparation of chiral D-lactic acid and its ester derivatives by enzymatic kinetic resolution was quite rare, probably because the structural difference of the two parts on the two sides of the ester bond was too small

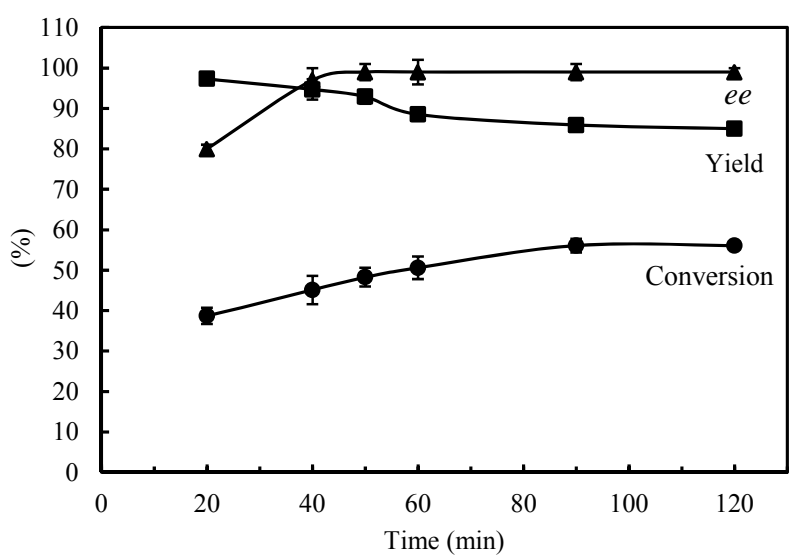

Fig. 5. Effect of reaction time on the kinetic resolution of $( \pm)$-methyl lactate. 
to be recognized by esterases. PHE14 is a novel marine microbial esterase which can recognize the chirality of racemic methyl lactate and generate valuable chiral D-methyl lactate with high enantiomeric excess and yield.

\section{Conclusions}

We identified and functionally characterized a novel esterase, PHE14, from the genome of Pseudomonas oryzihabitans HUP022 isolated from the deep sea of the western Pacific Ocean. Esterase PHE14 exhibited very good tolerance to most organic solvents, surfactants and metal ions tested. Esterase PHE14 also exhibited high resistance to high concentration $\mathrm{NaCl}$. Esterase PHE14 was utilized in the enzymatic preparation of D-methyl lactate by kinetic resolution. The desired product D-methyl lactate was obtained with an enantiomeric excess of $99 \%$ and a yield of $88.7 \%$ after process optimization. Thus, PHE14 was characterized to possess very good potential as a biocatalyst for asymmetric synthesis in industry.

\section{Acknowledgments}

We thank the research vessel KEXUE of the Chinese Academy of Sciences for collecting samples and WPOS sample center for providing samples. Constant help from Professor Jianhua Ju and Professor Changsheng Zhang is also greatly appreciated.

\section{References}

[1] R. N. Patel, Coord. Chem. Rev., 2008, 252, 659-701.

[2] R. N. Patel, Curr. Opin. Drug Discov. Dev., 2006, 9, 741-764.

[3] R. N. Patel, Enzyme Microb. Technol., 2002, 31, 804-826.

[4] C. Gao, J. H. Qiu, J. C. Li, C. Q. Ma, H. Z. Tang, P. Xu, Bioresour. Technol., 2009, 100, 1878-1880.

[5] R. Datta, M. Henry, J. Chem. Technol. Biotechnol., 2006, 81, 1119-1129.

[6] T. H. T. Vu, T. A. Hang, T. H. T. Nguyen, T. T. T. Nguyen, M. H. Do, N.
Q. Bui, N. Essayem, Catal. Lett., 2013, 143, 950-956.

[7] W. Su, Z. Y. Chang, K. L. Gao, D. Z. Wei, Tetrahedron Asymmetry, 2004, 15, 1275-1277.

[8] J. Y. Liang, Y. Zhang, A. J. Sun, D. Deng, Y. F. Hu, Appl. Biochem. Biotechnol., 2016, 178, 558-575.

[9] S. D. Zhou, T. B. Causey, A. Hasona, K. T. Shanmugam, L. O. Ingram, Appl. Environ. Microbiol., 2003, 69, 399-407.

[10] K. D. Ma, T. Maeda, H. You, Y. Shirai, Bioresour. Technol., 2014, 151, 28-35.

[11] D. Deng, Y. Zhang, A. J. Sun, J. Y. Liang, Y. F. Hu, Appl. Biochem. Biotechnol., 2016, 179, 75-93.

[12] A. Pesaresi, D. Lamba, Biochim. Biophys. Acta, 2005, 1752, 197-201.

[13] K. K. Kim, H. K. Song, D. H. Shin, K. Y. Hwang, S. Choe, O. J. Yoo, S. W. Suh, Structure, 1997, 5, 1571-1584.

[14] W. J. Zhu, Y. Li, H. H. Jia, P. Wei, H. Zhou, J. Min, Biotechnol. Lett., 2016, 38, 1-7.

[15] J. E. Choi, M. A. Kwon, H. Y. Na, D. H. Hahm, J. K. Song, Extremophiles, 2013, 17, 1013-1021.

[16] X. W. Jiang, X. W. Xu, Y. Y. Huo, Y. H. Wu, X. F. Zhu, X. Q. Zhang, M. Wu, Arch. Microbiol., 2012, 194, 207-214.

[17] K. C. Ko, S. O. Rim, Y. Han, B. S. Shin, G. J. Kim, J. H. Choi, J. J. Song, J. Ind. Microbiol. Biotechnol., 2012, 39, 681-689.

[18] N. Nawani, N. S. Dosanjh, J. Kaur, Biotechnol. Lett., 1998, 20, 997-1000.

[19] Y. M. Mohamed, M. A. Ghazy, A. Sayed, A. Ouf, H. El-Dorry, R. Siam, Sci. Rep., 2013, 3, 3358.

[20] H. Shao, L. Xu, Y. J. Yan, Int. J. Mol. Sci., 2014, 15, 16885-16910.

[21] M. Belcastro, T. Marino, N. Russo, M. Toscano, J. Mass Spectrom., 2005, 40, 300-306.

[22] S. S. Bae, Y. J. Kim, S. H. Yang, J. K. Lim, J. H. Jeon, H. S. Lee, S. G. Kang, S. J. Kim, J. H. Lee, J. Microbiol. Biotechnol., 2006, 16, 1826-1831.

[23] X. W. Jiang, Y. Y. Huo, H. Cheng, X. Q. Zhang, X. F. Zhu, M. Wu, Extremophiles, 2012, 16, 427-435.

[24] C. D. Santi, L. Ambrosino, P. Tedesco, L. Zhai, C. Zhou, Y. Xue, Y. Ma, D. D. Pascale, Biotechnol. Progr., 2015, 31, 890-899.

[25] A. J. R. Lasprilla, G. A. R. Martinez, B. H. Lunelli, A. L. Jardini, R. M. Filho, Biotechnol. Adv., 2012, 30, 321-328.

[26] K. Sakaki, N. Itoh, Biotechnol. Lett., 2003, 25, 1591-1595.

\section{Graphical Abstract}

Chin. J. Catal., 2016, 37: 1396-1402 doi: 10.1016/S1872-2067(16)62495-6

\section{Characterization of a marine microbial esterase and its use to make D-methyl lactate}

Yilong Wang, Yun Zhang, Aijun Sun, Yunfeng Hu*

South China Sea Institute of Oceanology, Chinese Academy of Sciences; University of Chinese Academy of Sciences;

South China Sea Bio-Resource Exploitation and Utilization Collaborative Innovation Center<smiles>COC(=O)[C@H](C)O</smiles>

racemic methyl lactate

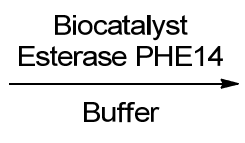<smiles>COC(=O)C(C)O</smiles>

D-methyl lactate ee $>99 \%$ yield $>88 \%$

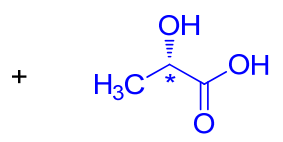

L-lactic acid

A novel marine microbial esterase PHE14 identified from the Western Pacific Ocean was functionally characterized and used as a green biocatalyst in the enzymatic preparation of D-methyl lactate, a key chiral chemical, with high enantiomeric excess (ee > 99\%) and high yield (> 88\%) through kinetic resolutions. 


\title{
一种新颖海洋微生物酯酶的功能鉴定及其在 D-乳酸甲酯制备中的应用
}

\author{
王依龙 ${ }^{\mathrm{a}, \mathrm{b}}$, 张 云 ${ }^{\mathrm{a}, \mathrm{c}}$, 孙爱君 ${ }^{\mathrm{a}, \mathrm{c}}$, 胡云峰 ${ }^{\mathrm{a}, \mathrm{c}, \mathrm{d},{ }^{*}}$ \\ $\mathrm{a}$ 中国科学院南海海洋研究所, 中国科学院热带海洋生物资源与生态重点实验室, 广东广州 510301 \\ b 中国科学院大学, 北京 100049 \\ c 中国科学院南海海洋研究所, 广东省海洋药物重点实验室, 广东广州 510301 \\ $\mathrm{d}$ 南海生物资源开发和利用协同创新中心，广东广州 510301
}

摘要: 手性药物不同对映体往往表现出截然不同的生理活性和毒性, 为了减少有毒副作用的对映体, 并降低其生物活性, 光学纯手性药物的合成一直是制药行业的研究热点. 由于手性药物中间体是合成手性药物的重要构建模块, 因此手性药 物中间体的合成至关重要. 手性乳酸及其酯是合成各类药物、农药和聚合物的重要中间体, 在制药工业和材料工业中手性 乳酸及其酯的制备非常重要. 手性乳酸及其酯可以通过传统的有机化学合成和生物酶催化合成, 通过有机化学合成法往 往很难得到光学纯度较高的手性乳酸及其酯, 而生物酶催化法可以得到光学纯的手性乳酸及其酯, 同时避免了有机化学合 成所导致的金属残留和环境污染等问题. 生物酶法合成光学纯的乳酸及其酯可以通过脱氢酶不对称还原酮的前体得到, 然而生物催化使用脱氢酶法需要价格昂贵的辅助因子, 如 NADH 和 NADPH. 而另外一种生物催化方法是通过利用酯酶 或者脂肪酶不对称水解外消旋的酯, 从而得到光学纯度较高的手性中间体. 目前市场上的 L-乳酸甲酯价格不太昂贵, 因为 L-乳酸甲酯可以直接通过大发酵的方法取代有机化学法和酶法直接得到. 然而 D-乳酸甲酯不能使用廉价的发酵法直接得 到, 因而其价格昂贵. 生物酶催化法可能会成为制备 D-乳酸甲酯的主要方法, 因为利用生物酶法可以得到光学纯度较高的 D-乳酸甲酯.

本文从西太平洋深海来源的微生物 Pseudomonas oryzihabitans HUP022 中克隆并异源表达了一种新颖酯酶 PHE14. 通 过对酯酶 PHE14 的酶学性质鉴定表明, 酯酶 PHE14 的最适反应底物为对硝基苯酚乙酸酯 (C2), 最适 pH 为 9.0, 最适温度 为 $60^{\circ} \mathrm{C}$. PHE14 催化最适反应底物 $\mathrm{C} 2$ 的活性达到 $293.07 \mathrm{U} / \mathrm{mg}, V \max$ 和 $\mathrm{Km}$ 分别为 $200 \mu \mathrm{M} /(\mathrm{mg} \cdot \mathrm{min})$ 和 $0.24 \mathrm{mmol} / \mathrm{L}$. 酯 酶 PHE14 对多种有机溶剂、表面活性剂和金属离子都具有非常好的耐受性. 深海微生物酯酶 PHE14 对高浓度 $\mathrm{NaCl}$ 具有 很好的耐受性, 在 $4 \mathrm{~mol} / \mathrm{L} \mathrm{NaCl}$ 存在下, 相对酶活力为 $71.4 \%$. 同时, 酯酶 PHE14 能够催化消旋乳酸甲酯的不对称水解反 应制备重要的手性化工产品 - D-乳酸甲酯.

与先前的一些酯酶拆分的报道不同, 有机溶剂和表面活性剂对酷酶 PHE14 催化的动力学水解反应没有促进作用. 而 且, 本研究是首次通过酶动力学水解拆分反应制备光学纯的 $\mathrm{D}$-乳酸甲酯. 经过实验优化, 在 $\mathrm{pH} 9.0$ 和 $30{ }^{\circ} \mathrm{C}$ 的条件下, 反 应产物 D-乳酸甲酯的对映体过量值和产率分别为 $99 \%$ 和 $88.7 \%$. 深海微生物酯酶 PHE14 作为一种绿色生物催化剂, 在多 种工业的不对称合成中都具有非常好的应用潜力.

关键词: 酯酶; 海洋微生物; 生物催化; 动力学拆分; D-乳酸甲酯; 水解反应

收稿日期: 2016-05-25. 接受日期: 2016-06-22. 出版日期: 2016-08-05.

*通讯联系人. 电话: (020)89024092; 传真: (020)84451672; 电子信箱: yunfeng.hu@scsio.ac.cn

基金来源：中国科学院战略性先导科技专项 (XDA11030404); 国家自然科学基金 (21302199); 广州市科技计划项目 (201510010012); 中国科学院重点项目 (KGZD-EW-606).

本文的英文电子版由Elsevier出版社在ScienceDirect上出版(http://www.sciencedirect.com/science/journal/18722067). 